\title{
A night to remember: perspectives on the watershed 2018 Quebec election
}

\author{
Éric Bélanger ${ }^{1}$. Jean-François Daoust ${ }^{2}$
}

Published online: 21 May 2020

(c) Springer Nature Limited 2020

\begin{abstract}
This article introduces a special issue that takes a close look at the outcome of the October 2018 Quebec election where a newly created party (the Coalition Avenir Québec) took power with a majority of seats. The special issue's five articles collectively examine different factors having played a role in shaping Quebec citizens' voting behavior in 2018 . The extent to which citizens decide to turn out at the district level and their vote choice calculus are both investigated. The latter is analyzed through the lens of long-term factors such as language, attitudes toward Quebec independence, and party identification, as well as more short-term factors such as policy preferences on emerging issues like immigration and the environment. While several contributions point toward an important, perhaps long-lasting, realignment of the Quebec party system, others also highlight some elements of continuity, bringing nuance to an overall explanation of the election's outcome.
\end{abstract}

Keywords Quebec · Elections · Parties · Vote choice · Nationalism · 2018 Quebec provincial election

We're stopped and blowing off steam. Something's wrong, I don't know what. Run into a bit of ice, I think.

- Titanic wireless operator John 'Jack' Phillips, movie A Night to Remember

Quebec's provincial party system has long been dominated by the same two major players, the Parti Libéral du Québec (PLQ) and the Parti Québécois (PQ).

Éric Bélanger

eric.belanger3@mcgill.ca

Jean-François Daoust

jf.daoust@ed.ac.uk

1 Department of Political Science, McGill University, 855 Sherbrooke Street West, Montreal, QC H3A 2T7, Canada

2 Politics and International Relations, University of Edinburgh, Chrystal Macmillan Building, 15a George Square, Edinburgh EH8 9LD, UK 


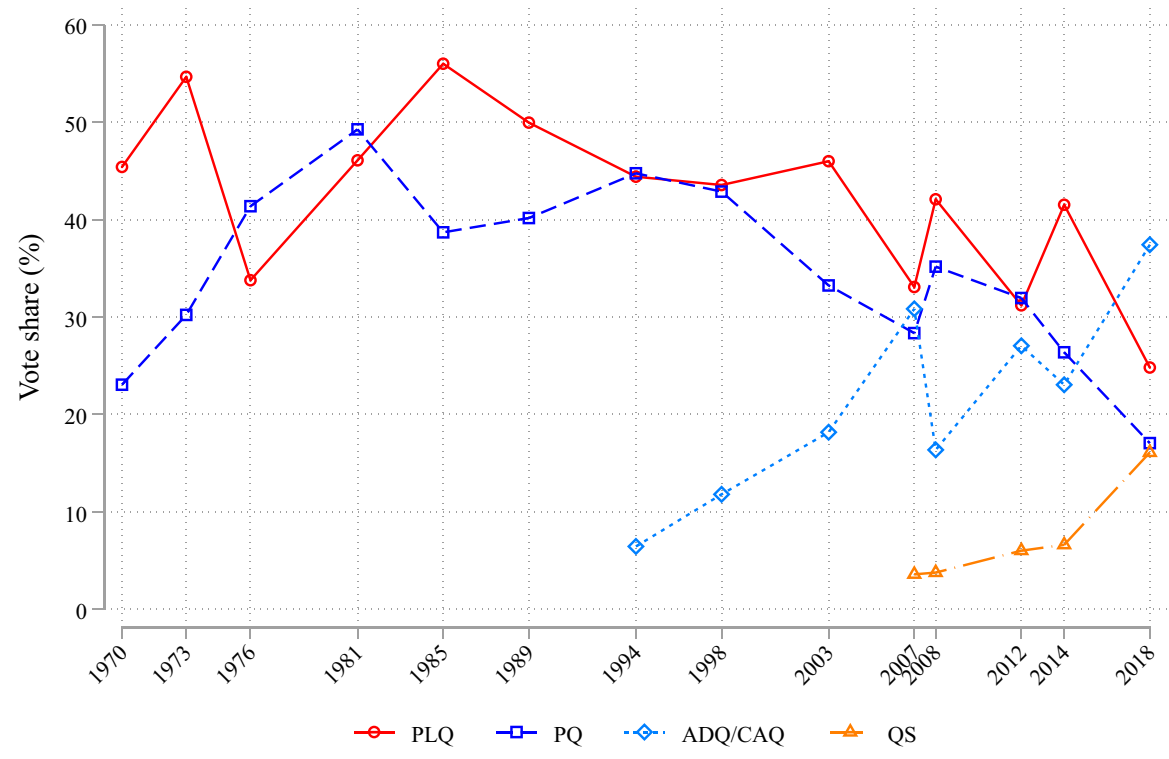

Fig. 1 Party performance in Quebec's third party system

Since 1970, these two political parties have alternated regularly at the head of Quebec's government. But on the fateful night of October 1, 2018, this two-party system may well have hit its proverbial iceberg. That "bit of ice" took the form of two emerging parties: the Coalition Avenir Québec (CAQ), which won that night's election with a landslide (74 seats out of 125, with 37.4\% of the vote); and Québec Solidaire (QS), which managed to elect 10 representatives and to double its vote share (from $7.6 \%$ in the preceding 2014 election to $16.1 \%$ ). In the process, the PLQ and the PQ each registered their lowest level of popular support ever $(24.8 \%$ and $17.1 \%$ of the vote, respectively). While it is still too early to know whether these two parties will be able to remain afloat and avoid sinking, there is no question that they are finding themselves in a (very) precarious position following the 2018 election's outcome.

The October 2018 Quebec election was a watershed one for many reasons. Voters granted a majority of seats in the Quebec National Assembly to the CAQ, a recent party created in November 2011-meaning that for the first time since 1970, neither the PLQ nor the PQ won the election. Moreover, the outcome was largely unexpected given that the campaign polls had overestimated the closeness of the race (Durand and Blais 2020). That said, there were early signs announcing this outcome. Figure 1 depicts the evolution of party vote shares in provincial elections between 1970 and 2018, a period that corresponds to Quebec's third party system (Pelletier 2012). ${ }^{1}$ The four parties currently represented in the Quebec National Assembly are

\footnotetext{
${ }^{1}$ Quebec's first two party systems ran from 1867 to 1936 (opposing the PLQ to the Parti Conservateur) and from 1936 to 1970 (opposing the PLQ to the Union Nationale).
} 


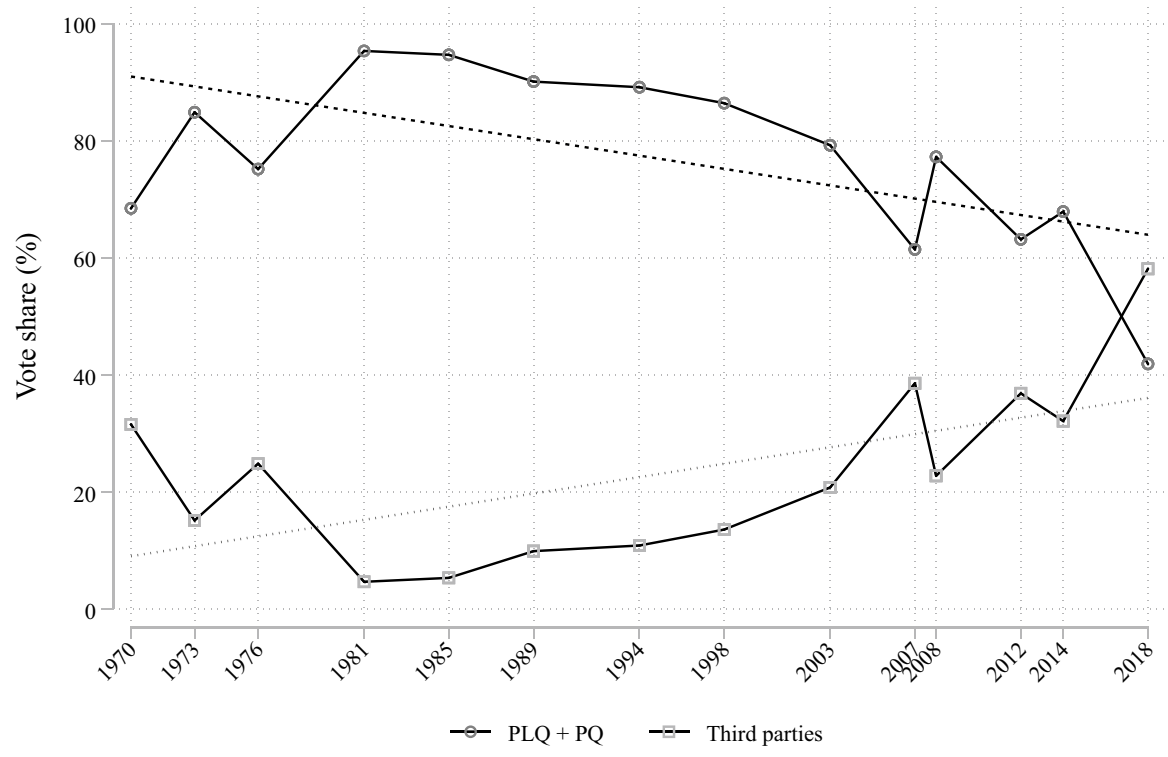

Fig. 2 The weakening two-party system and the rise of third parties (1970-2018)

included in this figure: the PLQ, the PQ, the CAQ (2011-) and its predecessor the Action Démocratique du Québec (ADQ, 1994-2012), ${ }^{2}$ and QS (2006-). As the figure indicates, while the increase in QS support is largely driven by the 2014-2018 movement, the ADQ/CAQ shows a clear positive trend since 1994. For their part, the PLQ and the PQ experienced some ups and downs, but overall, their vote share is in decline since the 1980 s, and especially since the 2007 election.

Figure 2 illustrates even more clearly the gradual weakening of the party system once dominated by the PLQ and the PQ. The top line in the figure shows the combined electoral support for these two governing parties while the other line represents the total vote share going to third (i.e., non-governing) parties. The trend is that the PLQ-PQ duopoly lost ground to the third parties since the early 1980s, and this tendency accelerated starting in 2007. While we do not know yet whether the victory of the CAQ in 2018 marked the beginning of a new (fourth) party system, it is already a historical event as it ended nearly half a century of alternation between the two governing parties.

The goal of this special issue of French Politics is to provide elements of explanation for understanding the outcome of the 2018 Quebec election. The five articles assembled here ${ }^{3}$ enhance our knowledge of Quebec politics and of this important

\footnotetext{
2 In February 2012, the ADQ merged with the CAQ just a few months after the creation of the latter; the ADQ thus did not compete in the following September 2012 provincial election.

3 Three of the issue's articles were first presented at a conference organized by us and held at McGill University on January 18th, 2019. The idea for the current special issue originated then. We thank the Centre for the Study of Democratic Citizenship, as well as its coordinator Wim Wolfs and its communications assistant Esther Armaignac, for their precious help in organizing this event. Additional financial support for holding the event came from a Social Sciences and Humanities Research Council of Canada Insight Grant awarded to Bélanger. We finally thank the conference's participants as well as the anony-
} 
event in many different ways, in terms of topics but also in terms of methodological approaches.

Regarding topics, the articles collectively look at a host of factors having played a role in determining Quebec voters' behavior, including long-term factors such as language, age cohorts, attitudes toward Quebec independence, and party identification, as well as more short-term factors such as policy preferences on emerging issues like immigration and the environment. The article by Daoust and Jabbour (2020) underlines the important loss of support over time for the PQ among Francophone voters, the (relative) decline of the national question in the vote choice calculus, and the greater propensity of the Millennial generation to support QS. Savoie et al.'s (2020) article shows how issue preferences on climate change and immigration are structured along clear ideological lines and are significantly related to Quebecers' vote choice in the 2018 election, mostly favoring the two new parties in the system (CAQ and QS). The article by Cossette-Lefebvre and Daoust (2020) goes deeper in the examination of the link between vote choice and an innovative attitudinal measure of "ethnic nationalism" and shows how in 2018 this factor has introduced a cleavage between the CAQ in one corner and the PLQ and QS in the other-sidelining the PQ in the process.

While several contributions do point toward an important, perhaps long-lasting, realignment of the party system, others also highlight some elements of continuity in voter turnout and citizens' vote choice calculus that provide nuance to an overall explanation of the 2018 election outcome. The articles by Bodet and VilleneuveSiconnelly (2020) and by Daoust and Jabbour (2020) provide a longitudinal perspective that is very useful. Looking at the district-level dynamics at work, Bodet and Villeneuve-Siconnelly (2020) show that the 2018 election outcome presents a return to patterns of turnout and support already displayed back in 2012, suggesting that the greater electoral participation of the non-Francophone population in the 2014 election (and the resulting victory of the PLQ) may well have been an exception to these patterns. For their part, Daoust and Jabbour (2020) find that, while the effect of support for Quebec independence on vote choice has declined since 2007, it remains a fundamental determinant of voting behavior, a conclusion that is clearly confirmed in the article by Savoie et al. (2020). In that same vein, the article by Brie and Ouellet (2020) shows that linguistic outgroup contact continues to have an impact on independence support despite the marginal place that the issue of Quebec independence occupied in the 2018 electoral campaign.

In terms of their methodological approach, the articles in this special issue make use of a variety of datasets and methods. Bodet and Villeneuve-Siconnelly (2020) rely on official aggregated data from Élections Québec. Brie and Ouellet (2020) conducted an exit poll which is a rarity in Quebec. Daoust and Jabbour (2020) combine survey data from five elections to build a unique cross-sectional time-series

Footnote 3 (continued)

mous reviewers and the editor (Amy Mazur) of French Politics, who all helped push forward our thinking about this election and the meaning of its outcome. 
dataset. Savoie et al. (2020) make use of a conjoint experiment, which has proven to be very efficient and popular in political science recently. Finally, Cossette-Lefebvre and Daoust (2020) exploit a rare multi-item question measuring nationalist attitudes that was never applied to Quebec politics but was embedded in a survey specifically designed to study the 2018 election.

This special issue is primarily meant as a contribution to the growing body of work on provincial voting behavior in Quebec, a field that was once vibrant (for notable edited volumes and monographs, see Lemieux 1969; Lemieux et al. 1970; Latouche et al. 1976; Bernard 1976; Bernard and Descôteaux 1981; Crête 1984) but that experienced a relative setback due to Quebec scholars' gradual shift of focus away from elections and toward independence referendums. Indeed, since the mid1980s monographs or edited collections specifically dedicated to the study of Quebec provincial elections have been much fewer (Monière and Guay 1995; Bélanger and Nadeau 2009; Bastien et al. 2013; Guay and Gaudreau 2018). Yet, as highlighted above, Quebec's party system and voting behavior have experienced considerable evolution lately, making them worthy of renewed scholarly attention. We believe that the collection of articles at hand makes substantial headways toward that goal.

The findings from these articles also have relevance for our understanding of Canadian politics more generally on at least two accounts. First, the relatively quick surge to power of the CAQ is but one of several recent cases of third-party success in the Canadian provinces (see Bélanger 2017). Similarly surprising rises of new parties, or of old parties having never formed a government before, have also occurred in the provinces of Saskatchewan (the Saskatchewan Party in 2007), Nova Scotia (the New Democratic Party in 2009) and Alberta (also the New Democratic Party in 2015). In addition, following the 2017 British Columbia election, the Green Party effectively held the balance of power in that province's legislature. In other words, the success of the CAQ is part of a trend in which provincial third parties in Canada are gaining more and more support and where traditional governing parties are finding it increasingly difficult to stay in power. This phenomenon suggests that party systems in Canada may be going through a period of profound change which may have part of its source in some common factors like the decline of electoral turnout or changes in the political cleavages that traditionally define party competition (Dalton et al. 2000). New issues can emerge (e.g., Ford and Jennings 2020), but also, existing ones' relative impact can change over time (e.g., Daoust and Dassonneville 2018).

Second, in terms of the preservation of Canada's national unity, the fact that the PQ, an independentist party, has been relegated to third place in the 2018 Quebec election may reassure some (for an early example of such a normative view, see Changfoot and Cullen 2011). However, one of the key findings that comes through in the analyses presented in this special issue is that the independence issue can only be characterized as being somewhat less of a mobilizing force at the ballot box in current times-particularly among youth — and should thus not be dismissed outright (see also Mahéo and Bélanger 2018). The question of Quebec's independence could become salient again depending on the political context-in particular, the state of Ottawa-Quebec (center-periphery) relationships. It also means that nationalism writ 
large is still very much salient in Quebec's electoral politics. Indeed, as some of the articles at hand show, nationalism-or, more precisely, its identity and grievance dimensions (see Bélanger et al. 2018) — is clearly one of the reasons for the CAQ's breakthrough in the first place.

Finally, the special issue's findings should be of interest not only to Quebec and Canadian scholars alike, but also to anyone interested in the study of elections and voting behavior in established democracies. The role of nationalism in electoral politics is not specific to the Quebec case but is a feature of party competition and voting behavior in many substate nations (e.g., Medeiros et al. 2015; Bélanger et al. 2018). While substate elections have long been thought to be "second-order" elections, in the sense that their outcome was thought to be largely explained by higher (state) level factors (Dinkel 1978; Jeffery and Hough 2003; Pallarés and Keating 2003; Hough and Jeffery 2006), the multidimensional nature of electoral politics in substate nations actually contributes to making substate elections "first-order" ones (Jeffery 2009a, b; Schakel and Jeffery 2013; Henderson and McEwen 2010, 2015; Golder et al. 2017; Thorlakson and Keating 2017; Bélanger et al. 2018). The case of the 2018 Quebec election thus provides additional evidence in favor of this interpretation of substate elections as being first order. The fact that this case seems to be a critical election also justifies taking an in-depth look at it so that it can shed light on the variety of factors leading to a rare political outcome such as party system change and the seemingly sudden evolution of voting behavior patterns (George and Bennett 2005).

Some of this special issue's main results also speak to the broader comparative literature on party and voting behavior. For instance, studies of substate nationalist parties have tended to categorize these formations as "niche" parties (e.g., Gunther and Diamond 2003; Adams et al. 2006; Meguid 2008; Jensen and Spoon 2010). While this characterization of nationalist parties as niche may be appropriate when considering state-level politics, it may be misleading when applied to the context of party competition at the substate level (Jeffery 2009b; Alonso et al. 2015; Elias et al. 2015; Bélanger et al. 2018). The case of the CAQ surge in Quebec is interesting precisely because it is a case of a nationalist party becoming mainstream, thus casting additional doubts about the appropriateness of the niche party label for describing the role and place of nationalist parties in substate nations.

Looking at the case of the 2018 Quebec election is also interesting because it provides further evidence of emerging issues, like immigration and the environment, disrupting party competition and voting behavior in established democracies. These new issue cleavages, which in the literature have mostly been associated with change in West European party systems (for a recent review, see Ford and Jennings 2020), are now starting to alter political behavior patterns elsewhere, with the Quebec case as one illustration of this. Such change reflects the evolution of voters' issue concerns. Political parties both respond to this evolution and contribute to reinforce it. While the rise of new issue cleavages is disruptive, the Quebec example shows-at least so far-that the change can, in the end, be moderate and that it is not necessarily bound to weaken democracy. But as with most everything in life, only time - and the study of future Quebec elections-will tell. 


\section{References}

Adams, J., M. Clark, L. Ezrow, and G. Glasgow. 2006. Are niche parties fundamentally different from mainstream parties? The causes and the electoral consequences of Western European parties' policy shifts, 1976-1998. American Journal of Political Science 50(3): 513-529.

Alonso, S., L. Cabeza, and B. Gómez. 2015. Parties' electoral strategies in a two-dimensional political space: Evidence from Spain and Great Britain. Party Politics 21(6): 851-865.

Bastien, F., É. Bélanger, and F. Gélineau (eds.). 2013. Les Québécois aux urnes. Montreal: Presses de l'Université de Montréal.

Bélanger, É. 2017. Third parties in Canada: Variety and success. In Canadian parties in transition, 4th ed, ed. A.-G. Gagnon and A.B. Tanguay, 185-214. Toronto: University of Toronto Press.

Bélanger, É., and R. Nadeau. 2009. Le comportement électoral des Québécois. Montreal: Presses de l'Université de Montréal.

Bélanger, É., R. Nadeau, A. Henderson, and E. Hepburn. 2018. The national question and electoral politics in Quebec and Scotland. Montreal \& Kingston: McGill-Queen's University Press.

Bernard, A. 1976. Québec: Élections 1976. Montreal: Hurtubise HMH.

Bernard, A., and B. Descôteaux. 1981. Québec: Élections 1981. Montreal: Hurtubise HMH.

Bodet, M.A., and K. Villeneuve-Siconnelly. 2020. Effective support and electoral dynamics in Quebec. French Politics. https://doi.org/10.1057/s41253-020-00118-6.

Brie, E., and C. Ouellet. 2020. Exposure to English as a determinant of support for Quebec independence in the 2018 Quebec elections. French Politics. https://doi.org/10.1057/s41253-020-00119-5.

Changfoot, N., and B. Cullen. 2011. Why is Quebec separatism off the agenda? Reducing national unity crisis in the neoliberal era. Canadian Journal of Political Science 44(4): 769-787.

Cossette-Lefebvre, H., and J.-F. Daoust. 2020. Nationalist and cosmopolitan approaches to the nation: A citizen's perspective and its electoral impact. French Politics. https://doi.org/10.1057/s41253-02000121-x.

Crête, J. (ed.). 1984. Comportement électoral au Québec. Chicoutimi: Gaëtan Morin.

Dalton, R.J., I. McAllister, and M.P. Wattenberg. 2000. The consequences of partisan dealignment. In Parties without partisans: Political change in advanced industrial democracies, ed. R.J. Dalton and M.P. Wattenberg, 37-63. Oxford: Oxford University Press.

Daoust, J.-F., and R. Dassonneville. 2018. Beyond nationalism and regionalism: The stability of economic voting in Canada. Canadian Journal of Political Science 51(3): 553-571.

Daoust, J.-F., and A. Jabbour. 2020. An extraordinary election? A longitudinal perspective of the Quebec 2018 election. French Politics. https://doi.org/10.1057/s41253-020-00120-y.

Dinkel, R. 1978. The relationship between federal and state elections in West Germany. In Elections and parties, ed. M. Kaase and K. von Beyme, 53-190. London: Sage.

Durand, C., and A. Blais. 2020. Quebec 2018: A failure of the polls? Canadian Journal of Political Science 53(1): 133-150.

Elias, A., E. Szöcsik, and C.I. Zuber. 2015. Position, selective emphasis and framing: How parties deal with a second dimension in competition. Party Politics 21(6): 839-850.

Ford, R., and W. Jennings. 2020. The changing cleavage politics of Western Europe. Annual Review of Political Science 23: 295-314.

George, A.L., and A. Bennett. 2005. Case studies and theory development in the social sciences. Cambridge: MIT Press.

Golder, S.N., I. Lago, A. Blais, E. Gidengil, and T. Gschwend. 2017. Multi-level electoral politics: Beyond the second-order election model. Oxford: Oxford University Press.

Guay, J.-H., and S. Gaudreau. 2018. Les élections au Québec: 150 ans d'une histoire mouvementée. Quebec: Presses de l'Université Laval.

Gunther, R., and L. Diamond. 2003. Species of political parties: A new typology. Party Politics 9(2): 167-199.

Henderson, A., and N. McEwen. 2010. A comparative analysis of voter turnout in regional elections. Electoral Studies 29(3): 405-416.

Henderson, A., and N. McEwen. 2015. Regions as primary political communities: A multi-level comparative analysis of turnout in regional election. Publius: The Journal of Federalism 45(2): 189-215.

Hough, D., and C. Jeffery (eds.). 2006. Devolution and electoral politics. Manchester: Manchester University Press. 
Jeffery, C. 2009a. New research agendas on regional party competition. Regional and Federal Studies 19(4-5): 639-650.

Jeffery, C. 2009b. Multi-level party competition in federal and regional states. In Handbook on multilevel governance, ed. H. Enderlein, S. Walti, and M. Zurn, 136-152. Cheltenham: Edward Elgar Publishing.

Jeffery, C., and D. Hough. 2003. Regional elections in multi-level systems. European Urban and Regional Studies 10(3): 199-212.

Jensen, C.B., and J.-J. Spoon. 2010. Thinking locally, acting supranationally: Niche party behaviour in the European parliament. European Journal of Political Research 49(2): 174-201.

Latouche, D., G. Lord, and J.-G. Vaillancourt (eds.). 1976. Le processus électoral au Québec: Les élections provinciales de 1970 et 1973. Montreal: Hurtubise HMH.

Lemieux, V. (ed.). 1969. Quatre élections provinciales au Québec. Sainte-Foy: Presses de 1'Université Laval.

Lemieux, V., M. Gilbert, and A. Blais. 1970. Une élection de réalignement: l'élection générale du 29 avril 1970 au Québec. Montreal: Éditions du Jour.

Mahéo, V.-A., and É. Bélanger. 2018. Is the Parti Québécois bound to disappear? A study of the current generational dynamics of electoral behaviour in Quebec. Canadian Journal of Political Science 51(2): 335-356.

Medeiros, M., J.-P. Gauvin, and C. Chhim. 2015. Refining vote choice in an ethno-regionalist context: Three-dimensional ideological voting in Catalonia and Quebec. Electoral Studies 40: 14-22.

Meguid, B.M. 2008. Party competition between unequals: Strategies and electoral fortunes in Western Europe. Cambridge: Cambridge University Press.

Monière, D., and J.-H. Guay (eds.). 1995. La bataille du Québec, deuxième épisode: Les élections québécoises de 1994. Montreal: Fides.

Pallarés, F., and M. Keating. 2003. Multi-level electoral competition: Regional elections and party systems in Spain. European Urban and Regional Studies 10(3): 239-255.

Pelletier, R. 2012. L'évolution du système de partis au Québec: un bipartisme tenace. In Les partis québécois dans la tourmente: mieux comprendre et évaluer leur rôle, ed. R. Pelletier, 19-40. Quebec: Presses de l'Université Laval.

Savoie, J., C. van der Linden, and C. Breton. 2020. Realignment and voter issue preferences in Quebec's 2018 provincial election: A conjoint experiment. French Politics. https://doi.org/10.1057/s4125 3-020-00123-9.

Schakel, A.H., and C. Jeffery. 2013. Are regional elections really 'second-order' elections? Regional Studies 47(3): 323-341.

Thorlakson, L., and M. Keating. 2017. Party systems and party competition. In Constitutional politics and the territorial question in Canada and the United Kingdom, ed. M. Keating and G. Laforest, 135-158. Basingstoke: Palgrave Macmillan.

Publisher's Note Springer Nature remains neutral with regard to jurisdictional claims in published maps and institutional affiliations. 